\title{
The Russian influenza in Sweden in 1889-90: an EXAMPLE OF GEOGRAPHIC INFORMATION SYSTEM ANALYSIS
}

\author{
L Skog (lars.skog@esri-sgroup.se) ${ }^{1}$, H Hauska ${ }^{1}$, A Linde $^{2}$ \\ 1. Division of Geoinformatics, Royal Institute of Technology, Stockholm, Sweden \\ 2. Department of Epidemiology, Swedish Institute for Infectious Disease Control, Solna, Sweden
}

Using data from a study of the 1889-90 Russian flu in Sweden, this article describes how the application of Geographic Information System (GIS) may improve analyses and presentation of surveillance data. In 1890, immediately after the outbreak, all Swedish doctors were asked to provide information about the start and the peak of the epidemic, and the total number of cases in their region and to fill in a questionnaire on the number, sex and age of infected persons in the households they visited. General answers on the epidemic were received from 398 physicians and data on individual patients were available for more than 32,600 persons. These historic data were reanalysed with the use of GIS, in map documents and in animated video sequences, to depict the onset, the intensity and the spread of the disease over time. A stack diagram with the observations grouped into one week intervals was produced to depict the spread in one figure only. To better understand how the influenza was disseminated, Thiessen polygons were created around 70 places reported on by the doctors. Having prepared GIS layers of the population (divided into parishes), estimations could be made for all the Swedish parishes on the number of infected persons for each of the 15 weeks studied. The described models may be useful in current epidemiological investigations, as well.

\section{Introduction}

The aim of this paper is to demonstrate how Geographic Information System (GIS) improves prospective surveillance and our knowledge on the diffusion of influenza epidemics. As an example we describe the application of this method to analyse historic data on the Russian influenza epidemic of 1889.

The cause of influenza was disputed in the 19th century. One old theory dating from the days of Hippocrates (460-377 $\mathrm{BC}$ ), saying that diseases are disseminated from miasma (bad or polluted air), had many advocates. Miasma was believed to come from decomposition in the ground, and attack weak individuals and occasionally cause disease outbreaks [1]. In "The History of Epidemics in Britain (1891-1894)", the well known British epidemiologist, Charles Creighton, tried to prove the miasmatic theory [2]. When his works were published, England and the rest of the world had just suffered from an influenza pandemic more severe than its predecessors. It was named Asiatic or Russian influenza, as the first reports of incidences came from a small village in the Asian part of Russia. It was detected in May 1889, reached St Petersburg in October and spread all over the world within a year.
On 4 February 1890, the Swedish Society for Medical Doctors assembled to discuss how the Russian influenza, at that time peaking in Sweden, was disseminated. The Society decided to undertake an epidemiological study to find the answer. A survey in the form of postal cards and a questionnaire were sent to all Swedish doctors. The results were collected by Dr Klas Linroth (1848-1926), Sanitary Inspector in Stockholm, in cooperation with Dr Curt Wallis and Dr Fredrik Warfvinge. Linroth analysed the results and concluded that the disease was spread along the communication network from person to person and not by miasma [3]. Linroth's main conclusions concerning the disease are presented in Table 1, to provide a general background for the geographic analyses made in this study.

Using Linroth's data this work intends to show how modern GIS technology can be used to add a geographic dimension to epidemiological analysis in order to facilitate the evaluation of hypotheses, conclusions and decisions. We looked into the geographical aspects of Linroth's carefully conducted epidemiological surveillance and explored the GIS methods in combining epidemiological data with geographic and census data to extract new information. The use of standard formats

\section{T A B L E 1}

Main findings of the epidemiological study conducted by $\mathrm{K}$. Linroth during the Russian influenza epidemic in Sweden in 1889-90

\begin{tabular}{|l|l|}
\hline Duration & $\begin{array}{l}3 \text { months (end November 1889 - end } \\
\text { February 1890) }\end{array}$ \\
\hline Incubation time & $1-3$ days \\
\hline Duration of the disease & $2.3-9.4$ days \\
\hline $\begin{array}{l}\text { Proportion of the population } \\
\text { affected (men; women) }\end{array}$ & $60.7 \%(60.0 \% ; 61.1 \%)$ \\
\hline Proportion of infected by age-groups (in years) \\
\hline$<1$ & $36.2 \%(153 / 450)$ \\
\hline $1-10$ & $59.8 \%(4,938 / 2,956)$ \\
\hline $11-20$ & $65.3 \%(3,379 / 5,170)$ \\
\hline $21-40$ & $61.5 \% 6,162 / 10,014)$ \\
\hline $41-60$ & $62 \%(2,896 / 4,666)$ \\
\hline$>60$ & $47.2 \%(837 / 1,770)$ \\
\hline Excess mortality, Stockholm & $\begin{array}{l}0.13 \%(300 / 235,000 \\
\text { Stockholm })\end{array}$ \\
\hline
\end{tabular}


and techniques ensures that the results obtained can easily be shared between the authorities and communicated to the public. To understand the nature of a pandemic it is essential to study its progress in both space and time. Modern GIS has all the tools necessary to make this happen.

\section{Methods and results}

\section{The data sets}

The request from the Swedish Society of Medical Doctors to all Swedish doctors contained two forms; the first one was a postcard, with three questions:

1. When was the first influenza case detected in your district?

2. When do you consider that the epidemic in your district reached its peak?

3. How large, according to your opinion, was the percentage infected by the influenza?

The postcards (study 1 ) were returned by 398 doctors. From the answers a table was compiled and a map was drawn in 1890 , indicating when the influenza first appeared at different locations. To support the contagiousness theory an analysis of the railway network was done in relation to the onset of the outbreak. In the first week in December 1889, 12 of the 13 affected places outside Stockholm had railway stations. In another table Linroth demonstrated that by 20 December, $82 \%$ of reporting places with a railway station and $47 \%$ without one had been affected. Sea ports with daily communications to and from Stockholm were also attacked early. There is, however, an uncertainty concerning these results, as it was never quite clear to the respondents whether it was the first locally infected patient or the first infected individual arriving by train or by boat that should be regarded as the first case in a particular location.
The second form (study 2) was designed to assess the number, age and sex of patients infected in the doctors' districts. The doctors were asked to fill in a questionnaire for each household they visited, providing information on the number, sex and age of all persons in the household and of those that had had influenza. They were also asked to communicate any observation that could add to the understanding of the characteristics and the spread of the influenza. In total 126 forms were returned with information on 32,683 individuals $(0.68 \%$ of the total population in Sweden at the time) and 42 of the doctors added personal notes. Separately, Linroth received 115 letters with additional information. Linroth used these answers to compile a table giving detailed information on the development of the influenza at 69 locations.

\section{GIS data and analysis}

In the GIS study, both Linroth's tables were converted into Excel format. For unknown reason the first data set is in 5 days intervals, whereas the second (the more comprehensive one) is in one week intervals (Table 2). The tables were checked for inconsistencies and some of the place names were changed to the spelling of today, to enable interactive geocoding (giving geographical coordinates to address information). In ArcGIS (GIS software from ESRI Inc., US) the Excel tables could be spatially joined to a Multinet (geographic data from Tele Atlas NV, The Netherlands) layer, using the place names. New point layers were thus created to link Linroth's data to places with geographical coordinates.

A background map showing land and water and the communication network was obtained. In 1890, the railway network was the main communication system of the country. By courtesy of the Railway Museum in Gävle we received a digital copy of a map of the Swedish railroads of 1890 . As the geometrical quality of this map is not very

\begin{tabular}{|c|c|c|c|c|c|c|c|c|c|c|c|c|c|c|c|c|}
\hline $\begin{array}{r}\text { Object } \\
\text { ID }\end{array}$ & Name & 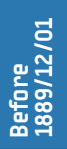 & 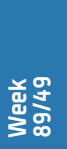 & 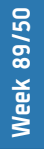 & 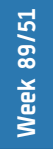 & 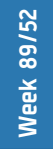 & 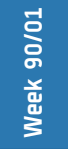 & 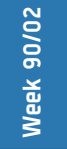 & 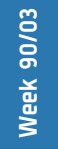 & 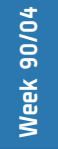 & 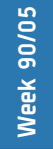 & 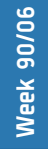 & 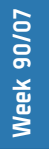 & 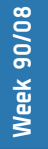 & 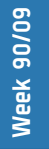 & 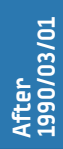 \\
\hline 6 & Karlskrona & & & 4 & 10 & 21 & 31 & 30 & 21 & 7 & 14 & 3 & & & & \\
\hline 7 & Eksjö & 1 & & 1 & 5 & 13 & 27 & 25 & 7 & 1 & 3 & 2 & 2 & 3 & 2 & \\
\hline 8 & Jönköping & & & 1 & 1 & 7 & 4 & 4 & & 1 & & & & & & \\
\hline 9 & Västervik & & & 2 & 2 & 30 & 73 & 67 & 42 & 18 & 6 & 6 & 1 & 2 & 3 & \\
\hline 10 & Värnamo & & & & & 81 & 50 & 12 & 3 & & 3 & 1 & 3 & & 2 & \\
\hline 11 & Söderåkra & & & & 1 & 9 & 13 & 12 & & & & & & & & \\
\hline 12 & Marstrand & 1 & 2 & 5 & 7 & 23 & 36 & 27 & 6 & 2 & & 1 & 4 & & & 4 \\
\hline 13 & Halmstad & & 1 & 8 & 13 & 39 & 61 & 57 & 20 & 12 & 6 & 4 & 2 & 3 & 3 & 1 \\
\hline 14 & Göteborg & & & 12 & 123 & 526 & 3525 & 2226 & 767 & 279 & 138 & 75 & 39 & 28 & & \\
\hline 15 & Skövde & & & & & 20 & 24 & 29 & 3 & & & & & & & \\
\hline 16 & Hjo & & & 7 & 13 & 54 & 133 & 169 & 102 & 5 & 23 & 16 & 11 & 2 & & \\
\hline 17 & Motala & & & & 12 & 44 & 59 & 58 & 2 & 2 & & 2 & & & & \\
\hline 18 & Linköping & & & & 18 & 65 & 95 & 36 & 13 & 2 & 3 & & & 4 & & 1 \\
\hline 19 & Eskilstuna & & & 1 & 23 & 60 & 299 & 171 & 115 & 14 & & & & & & \\
\hline 20 & Bettna & & & 1 & 6 & 13 & 33 & 32 & 3 & 2 & 1 & & & & & \\
\hline 21 & Österlövsta & & & 2 & 25 & 86 & 58 & 14 & 10 & 1 & 5 & 1 & 2 & & & \\
\hline 22 & Västerås & & & 3 & 8 & 18 & 16 & 2 & 2 & 2 & & & & & & \\
\hline
\end{tabular}


good, we decided to use the modern, geometrically satisfactory, railroad data from Tele Atlas instead. From the current (as of 2007) Tele Atlas railroad layer all railroads not existing in 1890 were manually deleted, using the museum map as master.

Using data from study 1 (onset of first cases) as well as the railway network, maps were created to show, in five-day intervals, how the epidemic spread in the country.

Similar maps were created on the basis of study 2 data. For each of the 15 weeks in the spread sheet (Table 2) from Linroth's second study, GIS layers were created, showing the number of infected persons at each location. These layers can be displayed in many different ways. Figure 2 shows places in Sweden where influenza was reported with the weekly incidences indicated by the size of the dots.

The map series in Figure 1 (with data from Linroth's first study) can be compared with the map series in Figure 2. The time intervals are slightly different but comparing the two map series one can still see the same pattern along the railways.

Using the same technique as was demonstrated in a previous study [4], time layers can be organised to create video sequences. This was done for both data sets and video clips can be supplied upon request to the authors.

We also managed to create maps with bar charts showing in one map (Figure 3) the progress of the disease week by week. This gives an understanding, in one single map, of how, where and when the influenza was spread.

Other researchers [5] have chosen to visualise local peaks of influenza in maps where each specific colour represents a specific time period (typically a month). Compared to this technique our method has the benefit of showing peaks that may vary in length of time.

\section{Modelling of spread, combining population and the epidemiological data}

The available data on the number of infected persons (study 2) refer only to 69 locations and the 32,683 infected individuals.
There is no information on the spread of the epidemic to other places. Thus, it is not known when and how many people in total were infected in Sweden.

A geodatabase of the Swedish population per parish and year has been created for another study, not yet published. The population data was gathered by Professor Lennart Andersson-Palm at the University of Gothenburg. By importing the parish boundaries along with population figures from 1890 into this study, the local impact of the influenza was geographically assessed, based on reported data from 69 locations.

Thereafter, to understand how the influenza was disseminated to all other places, the so called Thiessen (or Voronoi) polygons [6] were created around each of the 69 studied locations. All positions within a polygon are closer to the point location, around which the polygon was created, than to any other of the remaining 68 location points (Figure 4).

Furthermore, we assumed that influenza spread in the same way in all parishes.

Using a GIS tool called "Select by Location" [7] we can see, for example, that the Thiessen polygon surrounding Västerås has 90 parishes (the small polygons in the map in Figure 4) with their centroids within the surface of the polygon.

The 90 parishes were then merged into a new polygon. We called this polygon a "Thiessen area". This was repeated for each of the 69 Thiessen polygons, covering all of Sweden. It is important to note that the shorter the distances between the observation points are, the smaller the Thiessen areas get.

We then created an Excel sheet with the numbers of infected persons per Thiessen area (Table 3).

Next, this Excel sheet was spatially joined with the Thiessen area layer. Time layers were then extracted for each week. These layers were colour coded to show the magnitude of the influenza, per Thiessen area, for the week layer displayed (Figure 5). Using the ArcGIS Animation Manager [8], video sequences were created for the 15 weeks the influenza lasted. The video sequences can

TA B L E 3

Part of a spread sheet containing calculated numbers of infected persons per Thiessen area for each week during the influenza epidemic. Analysis of Russian influenza in Sweden in 1889-90

\begin{tabular}{|c|c|c|c|c|c|c|c|c|c|c|c|c|c|c|c|}
\hline Name & $\begin{array}{c}\text { Before } \\
1889 / 12 / 01\end{array}$ & $\begin{array}{l}\text { Week } \\
89 / 49\end{array}$ & $\begin{array}{l}\text { Week } \\
89 / 50\end{array}$ & $\begin{array}{l}\text { Week } \\
89 / 51\end{array}$ & $\begin{array}{l}\text { Week } \\
89 / 52\end{array}$ & $\begin{array}{l}\text { Week } \\
90 / 01\end{array}$ & $\begin{array}{l}\text { Week } \\
90 / 02\end{array}$ & $\begin{array}{l}\text { Week } \\
90 / 03\end{array}$ & $\begin{array}{l}\text { Week } \\
90 / 04\end{array}$ & $\begin{array}{l}\text { Week } \\
90 / 05\end{array}$ & $\begin{array}{l}\text { Week } \\
90 / 06\end{array}$ & $\begin{array}{l}\text { Week } \\
90 / 07\end{array}$ & $\begin{array}{l}\text { Week } \\
90 / 08\end{array}$ & $\begin{array}{l}\text { Week } \\
90 / 09\end{array}$ & $\begin{array}{c}\text { After } \\
1990 / 03 / 01\end{array}$ \\
\hline Vaxholm & 0 & 2292 & 24062 & 8021 & 1146 & 1146 & 0 & 0 & 0 & 0 & 0 & 0 & 0 & 0 & 0 \\
\hline Visby & 0 & 2973 & 811 & 4865 & 8649 & 9730 & 2973 & 2162 & 1351 & 811 & 270 & 0 & 0 & 0 & 0 \\
\hline Vrigstad & 0 & 0 & 0 & 5386 & 6155 & 20005 & 10003 & 3847 & 2308 & 0 & 0 & 0 & 0 & 0 & 0 \\
\hline Vålberg & 0 & 0 & 0 & 0 & 0 & 3553 & 7105 & 21316 & 3553 & 0 & 0 & 0 & 0 & 0 & 0 \\
\hline Värnamo & 0 & 0 & 0 & 0 & 21737 & 13418 & 3220 & 805 & 0 & 805 & 268 & 805 & 0 & 537 & 0 \\
\hline Västervik & 0 & 0 & 283 & 283 & 4252 & 10345 & 9495 & 5952 & 2551 & 850 & 850 & 142 & 283 & 425 & 0 \\
\hline Västerås & 0 & 0 & 5051 & 13469 & 30305 & 26937 & 3367 & 3367 & 3367 & 0 & 0 & 0 & 0 & 0 & 0 \\
\hline Åmål & 0 & 272 & 0 & 272 & 1630 & 2445 & 7879 & 8694 & 4075 & 2445 & 1087 & 0 & 0 & 272 & 0 \\
\hline Örebro & 342 & 856 & 1883 & 9242 & 10782 & 10611 & 4792 & 2054 & 1540 & 685 & 856 & 342 & 342 & 342 & 171 \\
\hline Österlövsta & 0 & 0 & 311 & 3890 & 13383 & 9026 & 2179 & 1556 & 156 & 778 & 156 & 311 & 0 & 0 & 0 \\
\hline Överkalix & 0 & 0 & 0 & 0 & 0 & 0 & 0 & 40 & 437 & 800 & 701 & 368 & 209 & 80 & 35 \\
\hline TOTAL & 4908 & 33825 & 123653 & 190456 & 435529 & 718155 & 575811 & 348406 & 185867 & 111512 & 70479 & 44338 & 14825 & 5943 & 7786 \\
\hline
\end{tabular}


Onset of Russian influenza epidemic in Swedish localities (data derived from study 1). Analysis of Russian influenza in Sweden in 1889-90.
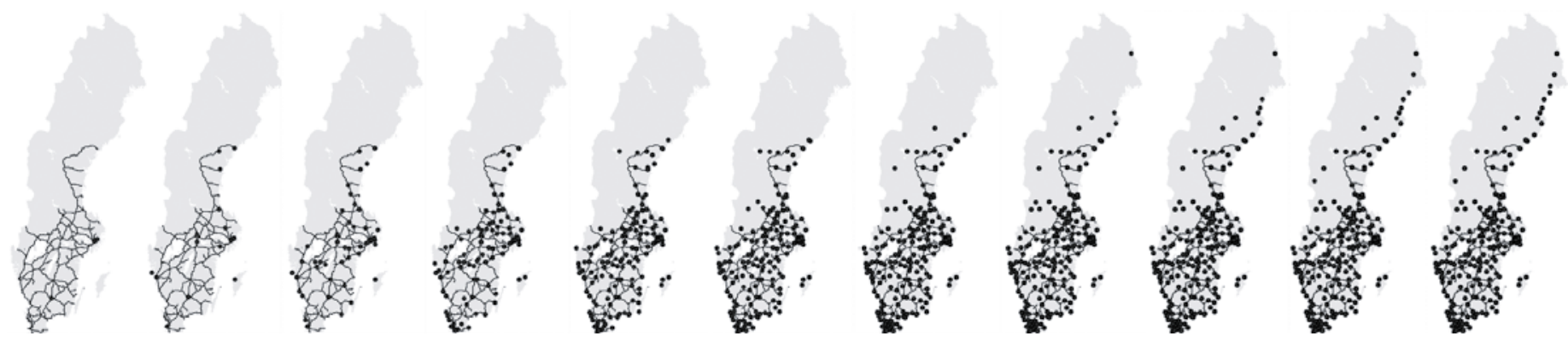

Dots represent places where first infected cases had been reported to date, maps correspond to five-day intervals, starting from the last week of November 1889 (left) until 21 January 1890 (right). The railroad network is shown.

\section{F I G U R E 2}

The numbers of infected patients reported by the local doctors within one-week intervals (study 2 ). Analysis of Russian influenza in Sweden in 1889-90.
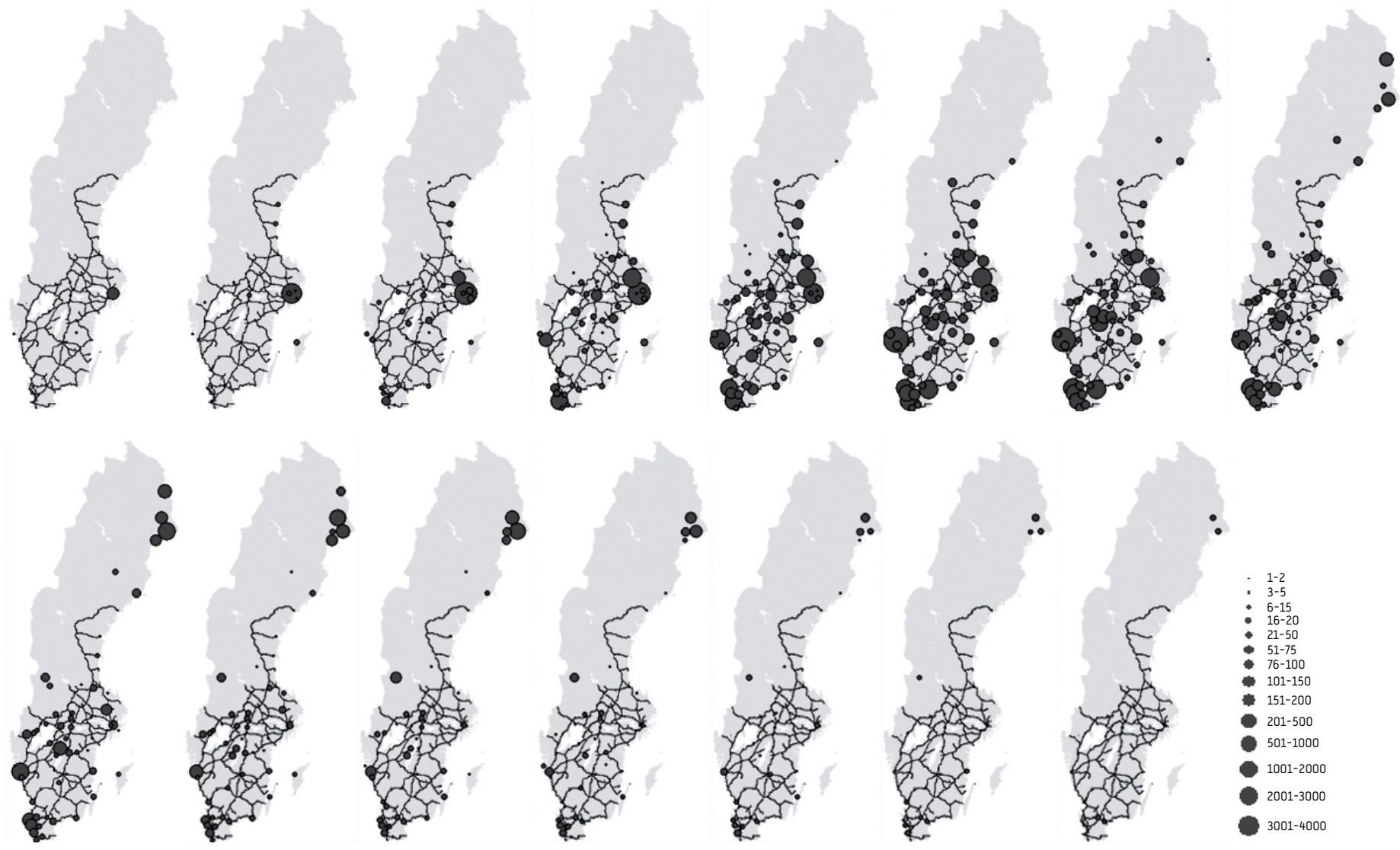

The dots indicate the number of cases; each map represents one week, starting from the last week of 1889 (upper left) and ending with the week of 1 March 1890 (lower right). The railroad network is shown.

For higher resolution colour maps, see: http://www.eurosurveillance.org/public/public_pdf/GIS_colour.pdf 
F I G U R E 3

A map with bar charts showing the intensity of the pandemic, week by week. Analysis of Russian influenza in Sweden in 1889-90.

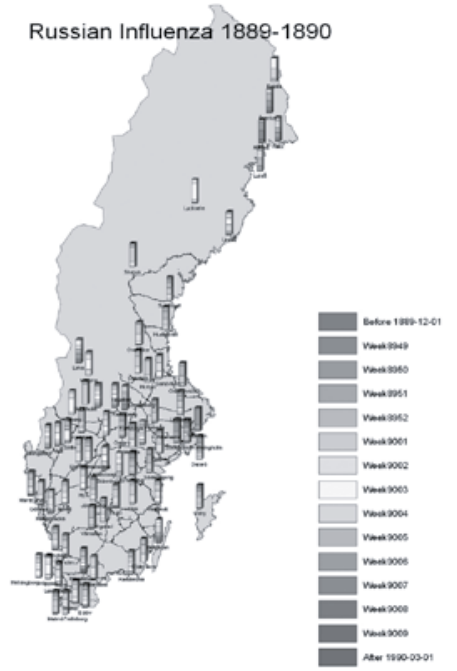

One colour (shade) represents one week. The heights of the respective coloured segments represent the relative intensity at each time period and location. The largest segments represent the local peaks in intensity. To interpret this map correctly it needs to be magnified at least $100 \%$.
F I G U R E 4

Thiessen polygons surrounding each of the observation points where cases had been reported by local doctors. Analysis of Russian influenza in Sweden in 1889-90.

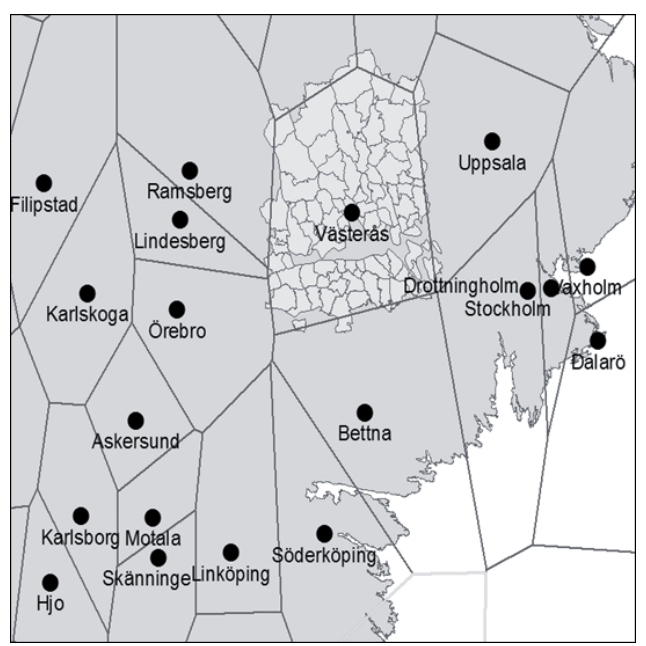

The small polygons represent parishes.

\section{F I G U R E 5}

The estimated cumulative total numbers of infected persons in Thiessen areas indicated by colour-coding. Analysis of Russian influenza in Sweden in 1889-90.
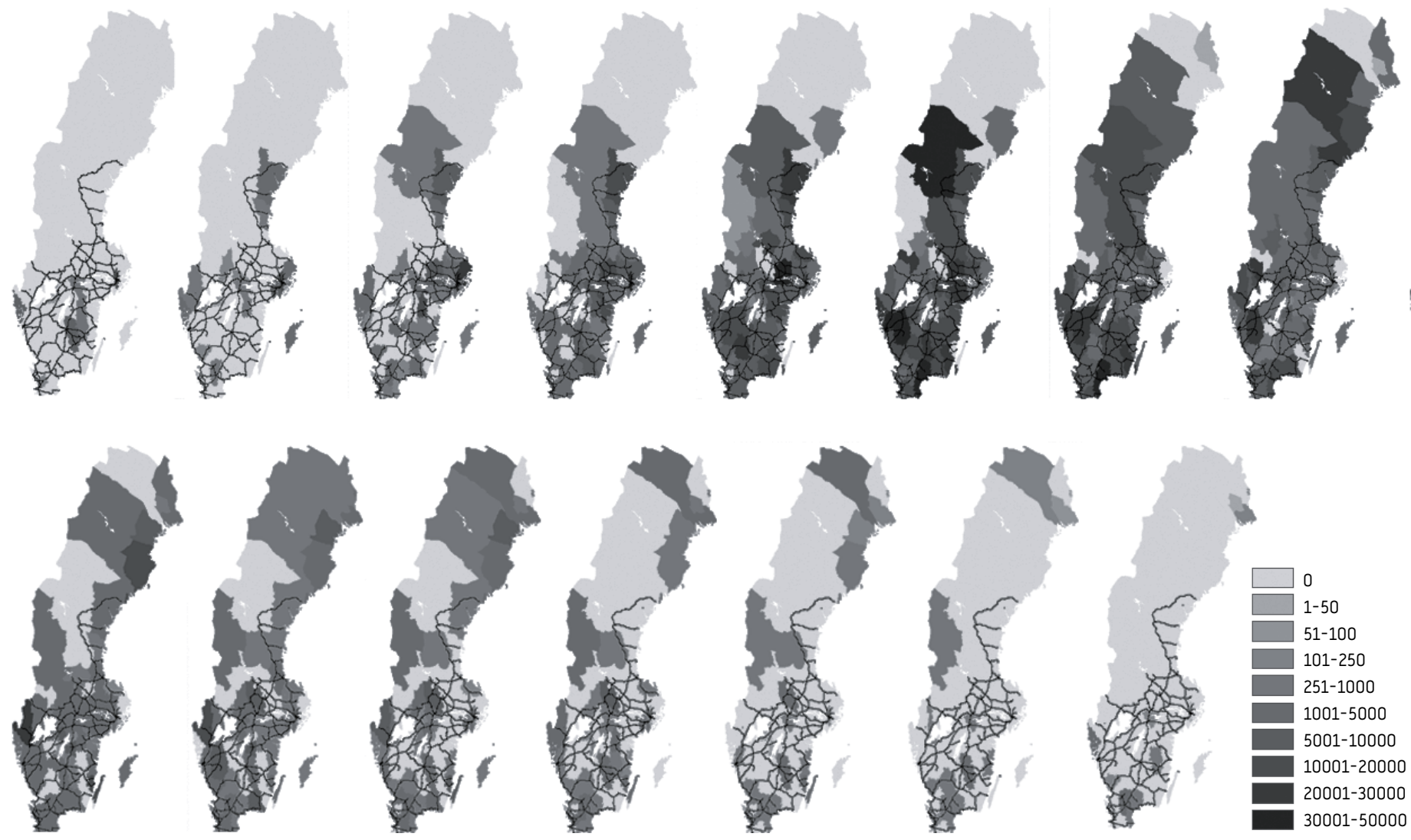

Darker colours mean more infected persons, varying from 0 to 50,000. The time difference between maps is one week, starting with the week of 1 December 1890 (upper left) and ending with the week of 1 March 1990 (lower right). The railroad network is shown. With fewer observation points in the north, the Thiessen areas there are accordingly larger in comparison with the southern parts of Sweden. 
be displayed in ArcMap or saved as video clips that may easily be distributed.

Using the above material it is possible to estimate how many infected persons there were for each of the 2,390 Swedish parishes (according to the administrative division of the country at that time) during the whole period of the Russian influenza epidemic in Sweden.

For example, the 90 parishes surrounding Västerås had a total population of 143,105 persons in 1890 . Taking into account Linroth's figures on the extent of the epidemic, the incubation time, dissemination speed and mortality, we conclude that $60 \%$ of the population of these parishes $(85,683$ persons) should have been infected by the Russian influenza and the number of deaths was approximately $260(0.3 \%$ mortality $)$. The epidemic was present in this area between week 50 of 1889 and week 4 of 1890, with a peak in the last week of 1889

\section{Discussion}

One of the basic reasons for $\mathrm{K}$. Linroth and his colleagues to start their study was to determine whether the influenza was a miasmatic or a contagious disease. Many of the respondents commented on that issue. Linroth claimed that the disease basically followed the transportation network (the railways and, in some cases, the seaways) in "a way typical for contagious diseases" (Linroth's words) but also for those diseases that were called contagious-miasmatic. Linroth does not define the meaning of contagious-miasmatic. He could be referring to Peter Ludwig Panum who in 1847 discussed the possible miasmatic-contagious character of measles [9].

The dissemination was very fast and the local epidemics developed at a pace that in some cases were described as explosive. Due to the general susceptibility, the short incubation time and the difficulty to detect the very first cases, more proof were needed to scientifically verify that the influenza was indeed contagious. Linroth was however of the opinion that the many individual testimonies describing how the infection was transferred directly from infected persons justified the hypothesis: Influenza is a contagious disease

The effects and the spread of the Russian flu were studied in many countries [10] and it can be regarded as a watershed in the history of influenza. It was the first influenza epidemic after the breakthrough of bacteriology. The miasmatic theory was thereafter not much heard of for many years. Modern studies on bioaerosols, however, to some extent support the theory of contagious-miasmatic disease dissemination. A new influenza virus was found in bioaerosols in 1968 and large quantities of influenza virus are suggested to be spread over the world as a bioaerosol, and EI Nino is said to have influenced the quick spread of bioaerosols in the atmosphere [11]. We believe that climate changes may influence the spread of influenza over the world, though this remains to be proven. Had GIS existed in the times of Linroth, addition of weather information to the study could have helped in verifying the theory of influenza being a contagious disease. Other modern explanations of the spread of influenza [12] claim that pathogens may be seeded in humans over a longer period of time and that host susceptibility varies in cycles.

Unfortunately it has not been possible for us to get access to the original data and answers from which Linroth compiled his tables. Also, there are obvious weaknesses in the Linroth study itself.
There were no clear definitions of the cases. The doctors answered voluntarily and in some cases off the top of their heads. There was an obvious lack of control system and data provided by the doctors was not verified. Still, the fact that they made so many home visits gave them a very good insight into the effects of the influenza.

The various applications of our GIS model illustrate visually what had previously been difficult or impossible to demonstrate. Concerning the spread model, it can of course be disputed whether the same temporal pattern can really be applied to all of the parishes with their centroids within a certain Thiessen polygon. Linroth collected evidence that locally the disease first appeared close to the place containing the railway station. The population living at distant houses and farms were infected at a later stage. It is our opinion though, that ours is the best assumption you can make based on the existing data, as there is no reliable information on where the influenza started in each region (polygon). Thiessen polygons are frequently used in several GIS applications. One example is the empirical modelling of government health service use by children with fevers in Kenya [13]. Another technique for generalisation is Kriging as described in T. Sakai et al. [5].

Additional advantage of the method presented is that GIS analyses can be made on site. This study has been performed using desktop GIS. There are many ways to make the established geodatabase public. Using a GIS web server, maps and data can easily be accessed and interrogated from web readers over Internet or an Intranet. Interactive questions can then be put to the geodatabase via the map interface by anyone (authorised) having access to a web reader.

In our time, influenza data from sentinel doctors are continuously collected at the Swedish Institute for Infectious Disease Control [14]. No more than 500-1000 patients are reported yearly. So far this has been regarded as too little for GIS work on monitoring and prediction. This year however, an evaluation of the usefulness of data collected for GIS analyses will be performed. In an ongoing study, 3,500 persons from all over Stockholm (positions are defined with zip code) continuously submit self-reports on influenza-like symptoms using a web application or over the phone via an interactive voice response [15]. The number of reporting individuals will be extended in 2009. We believe that GIS applications as described in this article will be extremely useful not only for visualisation of spread, but also for prediction and for identification of still unknown factors that may contribute to influenza epidemics.

\section{Conclusion}

Combining epidemiological data with additional available geographically oriented data clearly shows the power of GIS in epidemiological research, also in a historic perspective. In the study presented in this paper it made it possible to display the spatial patterns in time in tables, in video sequences and in single map documents showing temporal variations. Using the interactive map as an interface to the epidemiological data we were able to extend the analysis to a level where everyone involved in disease prevention and crisis management may have easy access to vital information, presented in an intuitive way. This can also be applied in case of information to the public. The techniques we used in this study can of course be used in other studies in epidemiology or related disciplines. How to implement these methods in crisis management should be further studied. 
Note: Lars Skog works for ESRI S-Group Sverige AB, provider of GIS and mapping software.

\section{References}

1. Collins C. Causes of fevers: miasma versus contagion. IBMS History zone. Institute of Biomedical Science [homepage on the internet]. http://www. ibms.org/index.cfm?method=science.history_zone\&subpage=history_fevers

2. Creighton C. The History of Epidemics in Britain. Oxford: Oxford University Press; 1894.

3. Linroth K. Influensan i Sverige 1889-1890 enligt iakttagelser af landets läkare, på Svenska läkaresällskapets uppdrag skildrad af Klas Linroth, Cur Wallis och F. W. Warfvinge. Del I: Influensan i epidemiologiskt hänseende. [Influenza in Sweden 1889-1890 according to observations of the country's doctors, description on request the Swedish medical society. Part 1: Influenza in epidemiological terms] [In Swedish]. Svenska Läkaresällskapets Nya Handlingar. Serie III. 1890:1-92.

4. Skog L. How can GIS Improve Epidemiological Work in Sweden? URISA “GIS in Public Health" Conference. 20-23 May 2007. [conference paper]

5. Sakai T, Suzuki H, Sasaki A, Saito R, Tanabe N, Taniguchi K. Geographic and temporal trends in influenzalike illness, Japan, 1992-1999. Emerg Infect Dis. 2004;10(10):1822-6.

6. Weisstein, Eric W. “Voronoi Diagram.” MathWorld - A Wolfram Web Resource. Available from: http://mathworld.wolfram.com/VoronoiDiagram.html

7. Using Select By Location [last modified 9 January 2008, accessed 24 March 2008]. ArcGIS 9.2. Desktop Help [homepage on the internet]. Available from: http://webhelp.esri.com/arcgisdesktop/9.2/index.cfm?TopicName=Using_ Select_By_Location

8. An overview of animation [last modified 13 July 2007, accessed 25 March 2008]. ArcGIS 9.2. Desktop Help [homepage on the internet]. Available from: http://webhelp.esri.com/arcgisdesktop/9.2/index.cfm?TopicName=An_overview_ of_animation

9. Panum P. Observations Made During the Epidemic of Measles on the Faroe Islands in the Year 1846. Copenhagen: Bibliothek for Laeger; 1847. 3R. 1:270-344. Available from: http://www.deltaomega.org/PanumFaroeIslands.pdf

10. Nicholson K, Webster RG, Hay A. Editors. Textbook of influenza. Oxford, UK: Blackwell Science, 1998.

11. Lofgren E, Fefferman NH, Naumov YN, Gorski J, Naumova EN. Influenza seasonality: underlying causes and modeling theories. J Virol. 2007;81(11):5429-36.

12. Dowell SF. Seasonal variation in host susceptibility and cycles of certain infectious diseases. Emerg Infect Dis. 2001;7(3):369-74.

13. Gething PW, Noor AM, Zurovac D, Atkinson PM, Hay SI, Nixon MS, Snow RW. Empirical modelling of government health service use by children with fevers in Kenya. Acta Trop. 2004;91(3):227-37.

14. Smittskyddsinstitutet (SMI) [Swedish Institute for Infectious Disease Control]. Influensarapport. Vecka 20 (12/5 - 18/5), 2008. Rapport om det aktuella influensaläget [Influenza report. Week 20 (12/5 - 18/5), 2008. Report on the current influenza situation]. [In Swedish]. Available from: http://www. smittskyddsinstitutet.se/publikationer/smis-nyhetsbrev/influensarapporter/ sasongen-20072008/influensarapport-vecka-20-2008/

15. Smittskyddsinstitutet (SMI) [Swedish Institute for Infectious Diseas Control]. Sjukrapport - frivillig influensaövervakning [Sickness report voluntary influenza surveillance]. [In Swedish]. Available from: http://www. smittskyddsinstitutet.se/publikationer/smis-nyhetsbrev/sjukrapport/

This article was published on 4 December 2008.

Citation style for this article: Skog L, Hauska H, Linde A. The Russian influenza in Sweden in 1889-90: an example of Geographic Information System analysis. Euro Surveill. 2008;13(49):pii=19056. Available online: http://www.eurosurveillance.org/ Surveill. 2008;13(49):pi1 $=19056$.
ViewArticle.aspx?ArticleId $=19056$ 